\title{
The Oxidative Stability of Biodiesel and its Impact on the Deterioration of Metallic and Polymeric Materials: a Review
}

\author{
Ernesto C. Zuleta, ${ }^{a}$ Libia Baena, ${ }^{b}$ Luis A. Rios ${ }^{a}$ and Jorge A. Calderón ${ }^{*, b}$ \\ ${ }^{a}$ Grupo Procesos Fisicoquímicos Aplicados and ${ }^{b}$ Centro de investigación, \\ Innovación y Desarrollo de Materiales (CIDEMAT), Sede de Investigación Universitaria, \\ Universidad de Antioquia and Calle 62 No. 52-59, Medellín, Colombia
}

\begin{abstract}
O objetivo deste artigo é analisar as principais questões com relação às estabilidades oxidativa e de armazenamento de biodiesel e como elas afetam diferentes materiais metálicos e poliméricos presentes em peças de automóvel e em estruturas de armazenamento de biodiesel. Adicionalmente, este trabalho apresenta uma revisão das técnicas para a medição da estabilidade oxidativa e para avaliação da degradação de materiais metálicos e poliméricos. Quando biodiesel é oxidado, ocorre uma série de mudanças nas suas propriedades, tais mudanças afetam não só a qualidade do biodiesel, mas também as propriedades dos materiais que estão em contato com o biodiesel. Com a oxidação, propriedades do biodiesel como o índice de acidez, índice de peróxidos e viscosidade aumentam, entretanto os índices de iodo e teor de ésteres metílicos diminuem. As alterações das propriedades químicas e físicas do biodiesel podem afetar a integridade e a estabilidade dos materiais que estão em contato com o combustível. A atual situação relacionada com a estabilidade dos materiais revistos neste artigo poderia limitar o uso extensivo de biodiesel, como tem sido proposto em vários países, e deveria ser considerada como um fenômeno de grande importância na tecnologia de biodiesel.
\end{abstract}

The purpose of this paper is to analyze the main issues concerned with the oxidative and storage stabilities of biodiesel and how they affect different metallic and polymeric materials present in automotive parts and in biodiesel storage structures. In addition, this work presents a review of the techniques used for measuring the oxidative stability and for evaluating the degradation of metallic and polymeric materials. When biodiesel is oxidized, a series of changes in its properties occurs. These changes not only affect biodiesel quality, but also the properties of the materials that are in contact with it. Upon oxidation, biodiesel properties like the acid value, peroxide value and viscosity increase, while the iodine value and the content of methyl esters decrease. The changes in the chemical and physical properties of biodiesel can affect the integrity and stability of the material. The situation reviewed in this paper, which talks about the stability of materials, could limit the extensive use of biodiesel. Such measures have been proposed in several countries, and it is a topic of great importance for biodiesel technology.

Keywords: biodiesel oxidation, antioxidants, metallic and polymeric materials, corrosion.

\section{Introduction}

Biodiesel, which is a relatively clean-burning, renewable fuel produced from new and used animal and vegetable oil, could be used to replace at least a portion of the diesel fuel consumed worldwide. Biodiesel has several advantages over regular petroleum diesel. First, it is not a petroleum-based fuel, which means that using biodiesel would reduce dependency on petroleum. Second, biodiesel

*e-mail: jacalder@udea.edu.co is domestically produced, which means that using biodiesel will create jobs and contribute to local economies. The third major advantage of biodiesel is that it is cleaner than conventional diesel; biodiesel produces significantly less harmful emissions than regular petroleum diesel when burned in a combustion engine. ${ }^{1}$ However, biodiesel also has some performance disadvantages. The performance of biodiesel in cold conditions is markedly worse than that of petroleum diesel. At low temperatures, biodiesel forms wax crystals, which can clog fuel lines and filters in a vehicle fuel system. The oxidative stability of biodiesel 
is also worse than the oxidative stability of diesel. This is a critical issue in industry because it affects the quality of the fuel and the materials in contact with it.

The autoxidation of lipids is a process investigated in many scientific fields as it occurs in both biological and chemical processes. Regarding the production and use of biodiesel, autoxidation is a critical phenomenon because it affects the quality of this fuel. Oxidation involves three stages: initiation, propagation and termination (Figure 1).

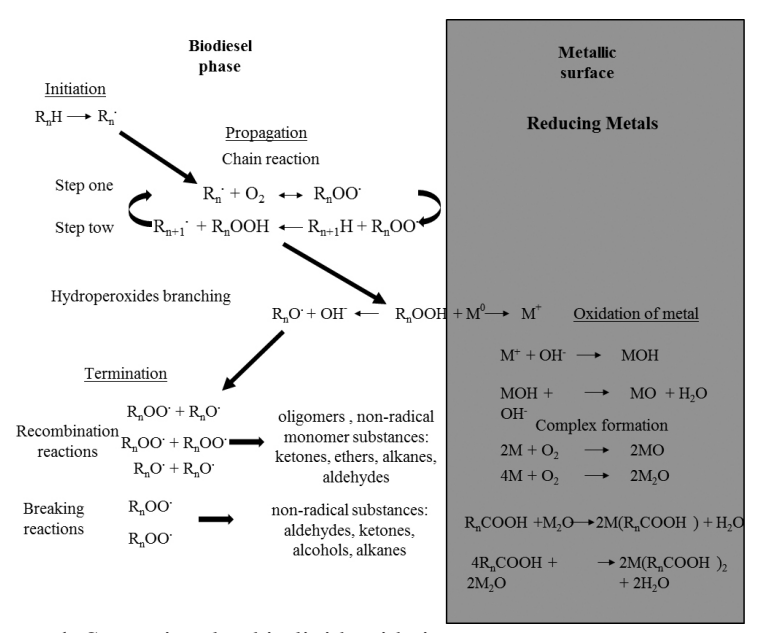

Figure 1. Stages involved in lipid oxidation.

In the initiation stage, a free radical attacks the lipid, abstracting an allyl hydrogen atom and generating an allylic radical $\left(\mathrm{R}_{\mathrm{n}}^{*}\right)$. The initiator is a free radical that is generally produced by the decomposition of hydroperoxide present in the fat, which in turn is produced by photooxidation, high temperatures or the presence of metal ions in the lipid's environment. Autoxidation is characterized by an induction period in which the concentration of free radicals increases until the autocatalytic propagation steps become dominant. At this stage, there are small increases in the oxidation products. ${ }^{2}$

The propagation stage consists of two steps. In the first step, the allylic radical $\left(\mathrm{R}_{\mathrm{n}}{ }^{*}\right)$ reacts with molecular oxygen to produce peroxy radicals $\left(\mathrm{R}_{\mathrm{n}} \mathrm{OO} *\right.$ ). In the second step, the peroxy radical abstracts another allyl hydrogen, producing an allylic hydroperoxide $\left(\mathrm{R}_{\mathrm{n}} \mathrm{OOH}\right)$ and a new allyl radical $\left(\mathrm{R}_{\mathrm{n}+1}{ }^{*}\right)$. This allyl radical again reacts with molecular oxygen, giving rise to a chain reaction. Because the second step is slower, the propagation stage is more decisive.

Hydrogen abstraction by the free radicals usually takes place at a specific site, occurring preferentially at the allyl hydrogen site where the bond energy between the carbon and hydrogen is low. Table 1 shows the bond energies between hydrogen and various positions in the fatty acid chains. The double allylic hydrogen that lies between two double bonds is more reactive than allylic hydrogen near a double bond because the former has a lower binding energy than the latter. ${ }^{3}$

Table 1. Bond energies of hydrogen in various positions in the carbon chain (enthalpy in the gas state of the weakest $\mathrm{H}-\mathrm{C}$ bond) $)^{3,4}$

\begin{tabular}{lc}
\hline Hydrogen position & $\mathrm{E}\left(\mathrm{kJ} \mathrm{mol}^{-1}\right)$ \\
\hline $\mathbf{H}-\mathrm{CH}=\mathrm{CH}_{2}$ & 431 \\
$\mathbf{H}-\mathrm{CH}_{2}-\mathrm{CH}_{2}-\mathrm{CH}_{3}$ & 419 \\
$\mathbf{H}-\mathrm{CH}_{2}-\mathrm{CH}=\mathrm{CH}_{2}$ & 356 \\
$\mathrm{R}-\mathrm{HCH}-\mathrm{CH}=\mathrm{CH}-\mathrm{CH}_{2}-\mathrm{CH}_{3}$ & 322 \\
$\mathrm{R}-\mathrm{CH}=\mathrm{CH}-\mathrm{HCH}-\mathrm{CH}=\mathrm{CH}-$ & 272 \\
\hline
\end{tabular}

During the termination stage, reactions take place removing radicals formed in the previous stages. The main reactions that occur are recombination reactions between the radicals to form monomers and polymers, and reactions that break the radicals into non-radical substances. The products of these reactions are alcohols, ketones, ethers, alkanes, organic acids, aldehydes and oligomers, among others. $^{3}$

As biodiesel is oxidized, a series of changes in its properties occurs. Properties like the acid value, peroxide value and viscosity increase, while the iodine value and content of methyl esters decrease..$^{5}$ All of these changes affect the quality of biodiesel, which is why oxidation is a phenomenon of great importance in biodiesel technology, as mentioned at the beginning.

Currently, the biodiesel used in automobiles is employed in mixtures from B5 to B20 (diesel with 5 and $20 \%$ vol. of biodiesel, respectively) depending on the location, with Australia, Europe and America all using different percentages. Due to problems associated with the compatibility of automotive parts, higher percentages of biodiesel have not been used. The corrosive effects of biodiesel are mainly caused by the presence of water and free fatty acids. ${ }^{6}$ In vehicles, the fuel is in direct contact with different parts of the engine, such as the fuel pump, fuel injector, pistons and piston rings. ${ }^{7}$ The incompatibility of copper, aluminum, zinc, brass and bronze with biodiesel has been proven. ${ }^{8,9}$ Due to its excellent solvent properties, biodiesel can dissolve elastomers, ${ }^{10}$ leaching their aromatic compounds, as well as additives intended to prevent hardening and cracking. In fact, biodiesel has been shown to cause swelling of nitrile rubber. ${ }^{11}$ Furthermore, oligomers produced during biodiesel oxidation can cause serious problems such as the plugging of fuel lines and fouling on surfaces in contact with the fuel. ${ }^{12}$

The purpose of this work is to review the oxidative and storage stabilities of biodiesel, and how they affect different 
metallic and polymeric materials present in automotive parts. Moreover, it presents a review of techniques for measuring oxidative stability and for evaluating the degradation of metallic and polymeric materials in contact with biodiesel.

\section{Techniques for Evaluating the Oxidation of Biodiesel}

There are different methods used to assess the degree of oxidation of biodiesel (in long-term storage tests) or to see how susceptible it is to oxidation. For both cases, the following methods have been reported: analyzing the iodine, ${ }^{13,14}$ peroxide ${ }^{15-17}$ and acid values; ${ }^{14,16-18}$ the thiobarbituric acid test; ${ }^{19}$ the methyl ester content; ${ }^{20}$ the oxidative stability index; ${ }^{17}$ infrared spectroscopy; ${ }^{21}$ thermogravimetry; ${ }^{21}$ differential scanning calorimetry (DSC); ${ }^{21,22}$ and nuclear magnetic resonance (NMR) spectroscopy ${ }^{21}$ among others..

Tests such as those that analyze the iodine, peroxide and acid values, and the thiobarbituric acid test evaluate the development of substances formed during the degradation of biodiesel (primary or secondary products of the reaction). These tests have been adapted from oxidation tests performed on fats and oils in the food industry.

The iodine value is a measure of the amount of unsaturated fats and oils and is expressed in terms of the number of $\mathrm{cg}$ of iodine absorbed per $\mathrm{g}$ of sample..$^{23}$ The iodine value is determined by iodometric titration, in which a sample is dissolved in an organic solvent and mixed with a solution of iodine monobromide ( $\mathrm{IBr}$ ) or iodine monochloride ( $\mathrm{ICl}$ ) in glacial acetic acid (the Wijs or Hanus reagent). After a specific time, potassium iodide and water are added and the liberated iodine is titrated with a solution of sodium thiosulphate (Figure 2). The change in the iodine value resulting from oxidation has been studied as an indicator of the oxidation reaction in storage conditions. ${ }^{13,14}$

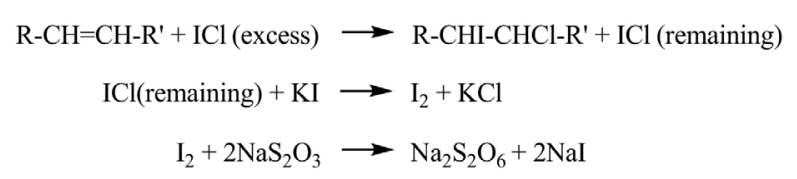

Figure 2. Determination of the iodine value.

The peroxide, or hydroperoxide, value measures the hydroperoxide content in oxidized oil, fat, fuel or other substance produced in the propagation step (Figure 1). The method consists of dissolving the sample in a suitable solvent (such as 2,2,4-trimethylpentane or chloroform) and adding an aqueous potassium iodide solution. The hydroperoxides present are reduced by the potassium iodide. An equivalent amount of iodine is liberated, being titrated with an aqueous sodium thiosulfate solution (Figure 3). Results are calculated as mg of hydroperoxide per $\mathrm{kg}$ of sample, expressed as the hydroperoxide number. ${ }^{24}$

$$
\begin{gathered}
\mathrm{ROOH}+2 \mathrm{KI}+2 \mathrm{H}^{+} \longrightarrow \mathrm{ROH}+\mathrm{I}_{2}+\mathrm{H}_{2} \mathrm{O}+2 \mathrm{~K}^{+} \\
\mathrm{I}_{2}+2 \mathrm{NaS}_{2} \mathrm{O}_{3} \longrightarrow \mathrm{Na}_{2} \mathrm{~S}_{2} \mathrm{O}_{6}+2 \mathrm{NaI}
\end{gathered}
$$

Figure 3. Determination of the peroxide value.

The acid number has been used to measure the acid products generated in oxidation reactions (fatty acids and other organic acids). The relative amount of acid products can be determined by titrating with base solutions (a solution of $\mathrm{KOH}$ in ethanol/water, generally). ${ }^{25}$ To determine the acid number, the sample is dissolved in an appropriated solvent and titrated with the base solution. The endpoint of the titration (neutralization) can be determined by the inflection curve in potentiometric titration or by an appropriate indicator that is added to the titration vessel. When the base used is $\mathrm{KOH}$, the acid number is expressed as mg KOH per $\mathrm{g}$ of sample.

The oxidative stability index (or simply oxidative stability) is a method that measures the formation of volatile acids. It monitors the change in electrical conductivity of a container with water when the oxidation products of biodiesel (or a lipid in general) pass through it. This index is defined as the point of maximum change of the oxidation rate, attributed to the increase in conductivity. ${ }^{26}$ It is one of the most important methods in the measurement and evaluation of the oxidation of biodiesel, and many works report its use. . $18,23,27-29,30-37^{-37}$

The European standard for biodiesel quality (EN 14214) uses the Rancimat method, developed by Hardon and Zürcher, for measuring oxidative stability. ${ }^{34}$ At present, Metrohm is the company that manufactures the Rancimat ${ }^{\circledR}$ equipment used for this method. The Rancimat method is an accelerated oxidation test under which biodiesel samples are heated to $110^{\circ} \mathrm{C}$, while an air flow of $10 \mathrm{~L} \mathrm{~h}^{-1}$ is passed over them. This air provides oxygen which oxidizes the samples and at the same time takes the oxidation products into a cell with water where an electrode measures the change in electrical conductivity. The variation of the conductivity with respect to time is recorded in a data storage system. Special software determines the induction time (IT), i.e., the time when a maximum increase in electrical conductivity occurs in the cell being measured (maximum turning point of the time curve versus conductivity, determined by the second derivative). ${ }^{38}$

DSC has also been reported as a technique for the rapid evaluation of the oxidative stability of biodiesel. ${ }^{26}$ 
This technique allows a profile or heat flow to be evaluated during the oxidation of biodiesel (exothermic) at a given temperature, and has been used in the evaluation of the effect of antioxidants on biodiesel. ${ }^{33}$ The proton nuclear magnetic resonance $\left({ }^{1} \mathrm{H} \mathrm{NMR}\right)$, which determines the positions of hydrogen atoms in molecules of biodiesel, has also been employed as an instrumental technique for assessing the molecular deterioration that oxidation causes. $^{26}$

\section{Storage Stability of Biodiesel}

The stability of biodiesel in storage is critical because oxidation reactions give rise to substances that can degrade different parts and materials used in biofuel storage systems. Several authors have investigated the behavior of biodiesel stored for long periods of time in contact with different materials, when exposed and not exposed to light and air. In general, changes have been reported regarding the iodine, ${ }^{13,14}$ peroxide, ${ }^{15-17}$ and acid values,,${ }^{14,16,18,20}$ as well as the viscosity, ${ }^{14,15}$ methyl ester content, ${ }^{20}$ oxidative stability ${ }^{17}$ and contend of insoluble material. ${ }^{38}$

Bouaid et al. ${ }^{14}$ evaluated the change in the iodine value (degree of unsaturation) in samples of biodiesel made from vegetable oils (sunflower and Brassica carinata) and waste oil, in a time period of 30 months, when exposed and not exposed to daylight. In general, all samples showed a decline in the initial iodine value, with this decline being sharper in the biodiesel samples with higher iodine values. Lin and $\mathrm{Chiu}^{13}$ evaluated the effect of oxidation on the properties of palm biodiesel during long-term storage. They found that as the storage time of palm oil biodiesel samples increases (125 days) their iodine value decreases. The samples stored at higher temperatures $\left(60^{\circ} \mathrm{C}\right)$ exhibited the highest rate of fall in the iodine value, while those to which antioxidant (butylated hydroxytoluene) was added or those that were stored at low temperatures $\left(20^{\circ} \mathrm{C}\right)$ had a lower rate of iodine value decrease.

The acid value increases with the formation of peroxides because the latter are transformed into aldehydes, which in turn oxidize into organic acids..$^{14,40}$ The acidity is also increased when the water that remains in the biodiesel causes the hydrolysis of esters, producing free fatty acids. ${ }^{14,28}$ Acidity is a parameter regulated by international standards for biodiesel. European (EN 14214) and American standards (ASTM 6751) limit maximum values to 0.5 and $0.8 \mathrm{mg} \mathrm{KOH} \mathrm{g}{ }^{-1}$, respectively. In many investigations of biodiesel stability in storage, these values are seen to be exceeded, as discussed below.

Leung et al. ${ }^{20}$ evaluated the degradation of rapeseed biodiesel samples over a period of 52 weeks under different storage conditions (sealed, exposed to air, sealed and with the presence of water, exposed to air and in the presence of water) and at different temperatures $\left(4,20\right.$ and $\left.40{ }^{\circ} \mathrm{C}\right)$. The acid value of the samples tested at a temperatures below $20^{\circ} \mathrm{C}\left(0.22 \mathrm{mg} \mathrm{KOH} \mathrm{g}^{-1}\right.$ at the beginning $)$ increased slightly at the end of the 52 weeks (less than $1 \mathrm{mg} \mathrm{KOH} \mathrm{g}^{-1}$ ), while the acid value of the samples stored at $40{ }^{\circ} \mathrm{C}$ increased significantly (between 17 and $20 \mathrm{mg} \mathrm{KOH} \mathrm{g}^{-1}$ ), especially for those samples exposed to air. Although water content promotes the hydrolysis of biodiesel, this process is more greatly affected by air exposure and high temperatures. ${ }^{20}$

Mittelbach and Gang $1^{17}$ found that the peroxide value of biodiesel made from rapeseed oil and waste vegetable oil increases with storage time, especially in samples exposed to air and light in which the peroxide value exceeds $300 \mathrm{mVal} \mathrm{O}_{2} \mathrm{~kg}^{-1}$ after 200 days of storage. Storage in the dark of the samples kept in plastic and metal containers causes a small increase in the peroxide values. Bouaid et al. ${ }^{14}$ evaluated the storage stability of biodiesel made from sunflower (Brassica carinata) and waste vegetable oil for thirty months and found that the samples exposed to daylight showed an increase in the peroxide value over time, with a sharper increase after the sixth month. The samples stored in the dark also show an increase in the peroxide value, but less so than those exposed to light.

Although the peroxide value is not regulated by the US and European standards, Dunn ${ }^{33}$ reported that the increase in this value in biodiesel increases the cetane number, reducing the ignition time (the time between fuel injection in the cylinder and the start of ignition). This can be explained by the fact that hydroperoxides are more reactive and accelerate the combustion of the mixture. However, Lin and $\mathrm{Chiu}^{37}$ reported that the cetane number of palm oil biodiesel samples decreases with storage time, contradicting the study published by Dunn. ${ }^{33}$ In their work, Lin and $\mathrm{Chiu}^{37}$ argue that the formation of oxidation products such as hydroperoxides, water, polymers and conjugated dienes causes the cetane number of palm biodiesel to decrease.

Viscosity affects the fuel injection into the engine combustion chamber. The higher the viscosity of a fuel, the greater its tendency to cause problems. ${ }^{36}$ The high viscosity of natural fats and oils is the main reason why they cannot be used directly in conventional engines. ${ }^{40}$ However, transesterification allows their viscosity to be reduced to values close to those of traditional diesel. The oxidation of biodiesel leads to the formation of high molecular weight polymer compounds that increase biodiesel viscosity, even exceeding the permitted values (between $5-6 \mathrm{~mm}^{2} \mathrm{~s}^{-1}$ according to international standards) if the oxidation time is long enough and conditions are extreme. 
Lin and $\mathrm{Chiu}^{13}$ evaluated the change in kinematic viscosity of palm oil biodiesel samples at $20{ }^{\circ} \mathrm{C}$ and at $60^{\circ} \mathrm{C}$, with and without antioxidant (butyl hydroxy toluene, BHT), during a storage period of $3000 \mathrm{~h}$. They found that biodiesel stored at a lower temperature and with antioxidant experienced the smallest increase in kinematic viscosity ( 6 to less than $6.5 \mathrm{cSt}$ ). The sample stored at $60{ }^{\circ} \mathrm{C}$ and without antioxidant had the highest increase in kinematic viscosity (from 6 to more than $9 \mathrm{cSt}$ ). The authors claim that during oxidation, the concentration of high molecular weight long-chain saturated fatty acids increases, particularly in the samples subjected to high temperatures. ${ }^{13}$ The biodiesel sample stored at $60^{\circ} \mathrm{C}$, with $0.1 \%(\mathrm{~m} / \mathrm{m})$ of BHT, began with a content of saturated fatty acids of $48.48 \%$ and increased to $52.47 \%$ after $1500 \mathrm{~h}$, and then to $54.52 \%$ after $3000 \mathrm{~h}$. This increase in the concentration of saturated compounds results in an increase in kinematic viscosity. ${ }^{13}$

Mittelbach and Gangl, ${ }^{17}$ Bouaid et al..${ }^{14}$ and Das et al. ${ }^{15}$ evaluated the viscosity of waste oil, vegetable oil and karanja oil biodiesel samples (Pongamia pinnata), respectively. In general, the authors report that, with a few exceptions, once the storage times have passed, little increase in the viscosity of biodiesels occurs. Bouaid et al. ${ }^{14}$ reported that only samples of biodiesel with a high water content and a high iodine value show a significant increase in viscosity. These results may be due to the fact that the long term oxidation tests developed in these studies were performed at low ambient temperatures $\left(20\right.$ to $25^{\circ} \mathrm{C}$ ), as reported by the authors.

\subsection{Formation of insoluble material during the storage of biodiesel}

There are substances that are present in biodiesel, or that may be formed during storage, which can eventually cause damage to fuel piping and filtration systems in distribution plants and even in vehicles. These substances are of a different nature, and will be described in this section.

As explained in the Introduction section, in the termination stage of biodiesel oxidation, insoluble oligomers of high molecular weight are produced by the recombination of oxidation products (Figure 1). Fang and McCormick ${ }^{12}$ proposed various routes for the formation of insoluble materials from biodiesel oxidation products. One route is via radical binding with another radical. Another is via radical binding with an oxidation product formed in the propagation step. In both cases, high-molecular weight and stable structures are formed, known as oligomers (Figure 4).

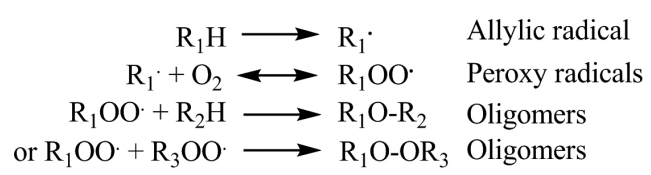

Figure 4. The formation of oligomers in biodiesel. ${ }^{12}$

Through aldol-condensation, it is possible to form various types of oligomers from the reaction between aldehydes and ketones, both of which are oxidation products of biodiesel. Fang and McCormick ${ }^{12}$ suggested that this would be the second major route for forming insoluble materials in biodiesel. The aldol-condensation products may further react with other substances and increase the size and molecular weight of insoluble products (Figure 5).

Aldehydes are formed by the scission of alkoxyl radicals $(\mathrm{RO} *)$. The recombination of secondary peroxyl radicals forms a variety of products including alcohols and ketones. ${ }^{3}$

Figure 5 shows the steps leading to the formation of aldehydes and ketones, and the reaction between these compounds to form insoluble materials. From the principal products of methyl oleate, methyl linoleate and methyl linolenate scission, Hancock and Leeves ${ }^{42}$ reported that the most abundant aldehydes were hexanal, pentanal, butanal,
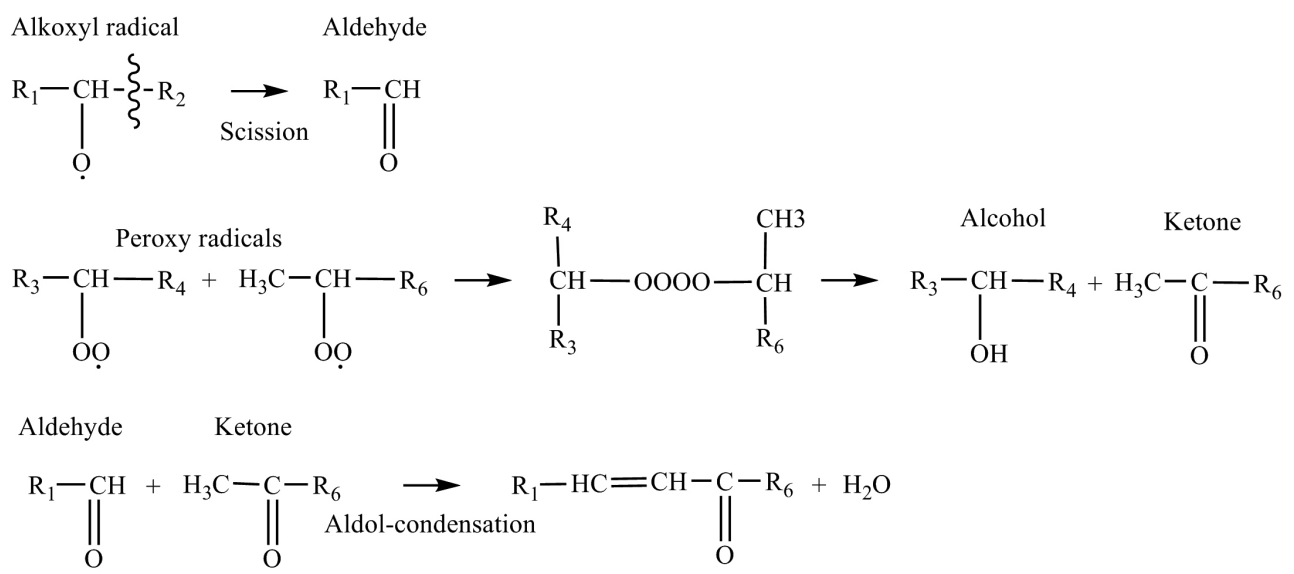

Figure 5. Aldol-condensation to form insoluble materials in biodiesel. ${ }^{13}$ 
2-heptanal, propanal and 2-pentanal. They stated that the most abundant ketones were 3-heptanone, 3-pentanone, 3-octanone, propanone and 1-penten-3-one. When the concentration of aldehydes or ketones reaches certain level, they can interact through aldol-condensation. ${ }^{12}$

Waynick ${ }^{39}$ suggested that vinyl polymerization is another route for the formation of insoluble material in biodiesel from methylester molecules and their oxidation products (Figure 6). In this polymerization, an allyl radical is added directly to a double bond to create a $\mathrm{C}-\mathrm{C}$ bond and another free radical. This free radical attacks another molecule to increase the molecular weight of the oligomer. Although it is not known how the free radical formed can react this way in an environment with the presence of oxygen, ${ }^{39}$ the conditions required for this reaction are present in the bottom of a storage tank.

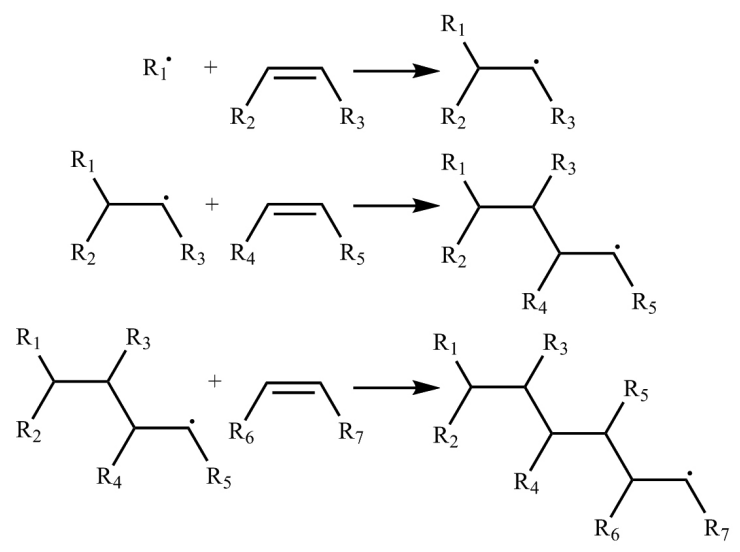

Figure 6. Formation of oligomers for vinyl polymerization. ${ }^{39}$

Through the Diels Alder reaction, the formation of oligomers between molecules in biodiesel is also possible. ${ }^{39,43}$ Figure 7 shows the formation of polymers through the binding of a methyl ester conjugate (two double bonds) with monounsaturated methylester using the Diels Alder reaction. Although conjugated dienes are found less in natural oils than non-conjugated dienes, during the course of hydroperoxide formation both cis/trans isomerization and the conjugation of unsaturated linkages can occur. ${ }^{42,44}$ According to the Diels Alder reaction, biodiesel produced from an oil with a high content of unsaturated and polyunsaturated fatty acids (e.g., flax oil biodiesel, sunflower oil biodiesel and soy oil biodiesel)

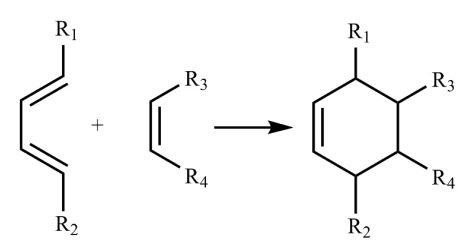

Figure 7. The formation of oligomers from the Diels-Alder reaction. ${ }^{39}$ would be more prone to form polymers at high temperatures (between 250 and $300{ }^{\circ} \mathrm{C}$ or more)..$^{39}$

The Diels-Alder reaction occurs at high temperatures and would not affect the storage of biodiesel. It is unclear how the dimers and trimers are formed by this reaction. ${ }^{39}$ The Diels-Alder reaction would explain the formation of carbonaceous deposits on the injection systems of diesel engines, which is commonly cited as an effect of the long term use of biodiesel. ${ }^{45,46}$ The formation of polymeric films on the nozzle by the Diels-Alder reaction, which are then subjected to high temperature, but do not burn well, eventually lead to the formation of the carbonaceous deposits cited.

Other substances in biodiesel that may eventually cause problems in the fuel storage system and automotive parts are produced by an incomplete transesterification reaction or an inadequate biodiesel purification process. ${ }^{47}$ Catalyst residues $(\mathrm{KOH}, \mathrm{NaOH})$ are turned into ash during combustion, which causes the formation of obstructions in the engine and leads to its progressive deterioration. ${ }^{45}$

The most commonly used industry-wide alcohol to produce biodiesel is methanol. ${ }^{41}$ The incomplete removal of this alcohol in the separation and purification process of biodiesel could promote the dissolution of polar compounds such as mono and diglycerides, free fatty acids, alcohol, water, glycerin and soaps. As methanol is evaporated from biodiesel, polar compounds agglomerate and settle at the bottom of storage fuel tanks and fuel tanks in vehicles, causing further problems. ${ }^{45}$

The above described phenomenon is aggravated by the presence of other compounds that are naturally found in oils and that are not completely removed in conventional refining systems. Among these substances, steryl glucosides can accelerate the formation of precipitates as a result of their polar nature and their limited solubility in biodiesel, even at room temperature due to their high melting point $\left(240{ }^{\circ} \mathrm{C}\right.$ for $\beta$-sitosteryl glucoside) ${ }^{48,49}$ In biodiesels with a high content of steryl glucosides, such as palm and soybean biodiesel, a haze can form at moderately high temperatures $\left(60{ }^{\circ} \mathrm{C}\right)$ in a relatively short time after production.

Steryl glucosides are derived from a phytosterol and a sugar (glucose) and are soluble in oils. During the process of transesterification, the acetylated form of steryl glucosides is converted into a free form, which is insoluble in biodiesel (see Figure 8). This causes a haziness that is enhanced by the presence of the polar compounds mentioned above. ${ }^{49}$

In plant tissues and vegetable oils, the free form and the acylated form (bound to a fatty acid) of steryl glucosides are found naturally. Under alkaline conditions, the ester linkage between glucose and fatty acid is broken, thereby forming the free form of steryl glucoside (Figure 8). ${ }^{50,51}$ 

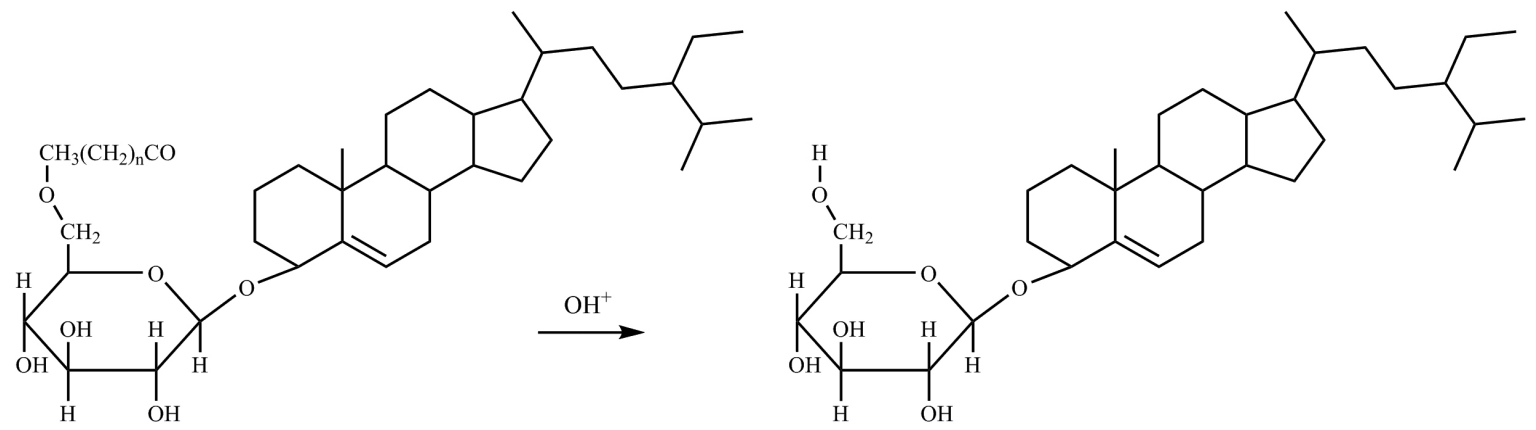

Figure 8. Transformation of acylated steryl glucoside (left) into free steryl glucoside (right).

This conversion occurs in conventional transesterification, implying that it is a phenomenon that potentially affects all worldwide industrial processes that produce biodiesel from oils with high contents of steryl glucosides.

In general, insoluble compounds of high molecular weight are able to obstruct the piping systems of motor fuels and are responsible for the formation of carbonaceous deposits in the fuel injectors of diesel engines. Slavinskas and Labeckas ${ }^{52}$ conducted a study to evaluate the effect of using rapeseed oil on the performance of a direct injection diesel engine single cylinder. They reported an accumulation of carbonaceous deposits on the injector probably due to products of high molecular weight formed during the oxidation of the rapeseed oil that are not completely burned.

Jayed et $a l .{ }^{45}$ reported that some authors have recommended that the status of the fuel injectors should be checked at least twice as often when using biodiesel due to the rapid formation of coke on the tip of the injectors. To prevent the formation of coke, Sgroi et al. ${ }^{53}$ suggested that the temperature of the injector nozzle should be maintained below $250{ }^{\circ} \mathrm{C}$. These authors proposed designing a cooled nozzle to maintain such temperature conditions. ${ }^{53}$

\section{Influence of the Composition of Biodiesel on its Stability}

The properties of biodiesel as a fuel, such as the cetane number, viscosity, heating value, cold flow, lubricity and oxidative stability, are determined by the structure of its alkyl esters. ${ }^{36}$ In terms of oxidative stability, the greater the degree of unsaturation, the greater its susceptibility to oxidation. This is because (as explained in the Introduction section) the hydrogens of the allylic and double allylic positions of unsaturated and polyunsaturated alkyl chains are easily oxidized.

According to Pinzi et al. ${ }^{54}$ the oxidation rate of biodiesel is more influenced by the composition of its alkyl esters than by environmental conditions (temperature, air, light and the presence of metals). Table 2 shows the values of the oxidative stability of some methyl esters, reported by Moser. ${ }^{22}$ As can be seen, a lower oxidative stability is obtained when a greater quantity of double bonds are present in the methyl ester.

Table 2. Oxidative stability of some methyl esters ${ }^{22}$

\begin{tabular}{lcc}
\hline Methyl ester & Carbon number:Unsaturation & $\begin{array}{c}\text { Oxidative stability } \\
\text { at } 110{ }^{\circ} \mathrm{C} \\
\text { (induction time / h) }\end{array}$ \\
\hline Laurate & $12: 00$ & $>40$ \\
Myristate & $14: 00$ & $>40$ \\
Palmitate & $16: 00$ & $>40$ \\
Palmitoleate & $16: 01$ & 2.1 \\
Stearate & $18: 00$ & $>40$ \\
Oleate & $18: 01$ & 2.5 \\
Ricinoleate & $18: 1 \mathrm{OH}$ & 1.6 \\
Linoleate & $18: 02$ & 1.0 \\
Linolenate & $18: 03$ & 0.2 \\
\hline
\end{tabular}

aStandard deviation: $\pm 0.1 \mathrm{~h}$

Different combinations of alkyl esters in biodiesel made from natural oils and fats result in a wide range of oxidative stabilities. Table 3 presents the oxidative stability of some biodiesels, as reported by various authors. Biodiesel made from palm oil has the highest induction time, and complies with international standards ( $6 \mathrm{~h}$ minimum to the European Standard EN 14214 and $3 \mathrm{~h}$ minimum to the American Standard ASTM D6751). ${ }^{55,56}$ In contrast, biodiesels made from sunflower, soybean, corn and beef fat oil have very low induction times and require the addition of antioxidants to achieve the induction time that the standards require.

In general, oxidative stability depends strongly on the concentration of linoleic and linolenic alkyl esters (polyunsaturated alkyl esters), rather than on the concentration of saturated and monounsaturated alkyl 
esters, even if the latter are in greater proportion than the former in the biodiesel mixture. This behavior has been reported by different authors who have investigated how the oxidative stability of mixtures of alkyl esters depends on their concentrations..$^{27,35,57,58}$

Knothe $^{27}$ proposed the allylic position equivalent (APE) and biss-allylic position equivalent (BAPE) as indices that relate the structure and amount of alkyl esters present in biodiesel with its oxidative stability. Some standards propose the iodine value as an indicator of biodiesel susceptibility to oxidation, but it has been shown that this index is correlated with low oxidative stability as well as the degradation of fatty acids and their products.

The APE and BAPE indices are based on the number of positions reactive to oxidation. For biodiesel, one APE is equivalent to one allylic position contained in an alkylester of $1 \%$ concentration in a mixture. In turn, one BAPE is equivalent to one double allylic position in an alkylester of $1 \%$ concentration in a mixture. The APE and BAPE indices are calculated by equations 1 and 2 .

$A P E=\sum_{n_{i} 1}^{i} a p_{i} \times A_{C i}$
$A P E=\sum_{n} a p_{i} \times A_{C i}$

where $a p_{i}$, is the number of allylic positions in the $i^{\text {th }}$ alkylester, bap $_{i}$ is the number of bis-allylic positions in the $i^{\text {th }}$ alkylester and $A_{C i}$ is the concentration of the $i^{\text {th }}$ alkylester in the biodiesel.
Park et al. ${ }^{57}$ studied the effect of fatty acid composition on the oxidative stability of biodiesel. To achieve this, mixtures of palm, canola and soybean oil biodiesel were prepared in different proportions and the oxidative stability was evaluated through Rancimat. It was found that the oxidative stability of the blends decreases when the total content of linoleic and linolenic acids increases. Based on this, some authors have proposed the blending of different biodiesels as a strategy to improve the oxidative stability. This procedure and some reported studies are discussed in the next section.

\section{Blending of Biodiesels to Improve the Oxidative Stability}

The blending of biodiesel from different oils is a technique that has been studied to improve the properties of this biofuel. Park et al..$^{57}$ studied blends of biodiesel from palm, rapeseed and soybean oil, and determined their effect on the oxidative stability and the cold filter plugging point. They concluded that when soybean biodiesel was blended with palm and rapeseed biodiesels, the oxidation stability of the blended biodiesel was improved. The high CFPP of palm biodiesel was also lowered by blending it with rapeseed and soybean biodiesels.

Moser $^{59}$ evaluated some fuel properties of soy biodiesel (oxidative stability, cold filter plugging point, cloud point, kinematic viscosity, lubricity, acid value and iodine value) and its mixture with methyl esters of palm, canola and sunflower. Moser ${ }^{59}$ concluded that the iodine

Table 3. Oxidative stability and alkyl-ester composition of some biodiesels

\begin{tabular}{|c|c|c|c|c|c|}
\hline Biodiesel & $\begin{array}{c}\text { Oxidative stability } \\
\text { at } 110^{\circ} \mathrm{C} \\
\text { (induction time } / \mathrm{h} \text { ) }\end{array}$ & $\begin{array}{c}\text { Saturated alkyl } \\
\text { esters / \% }\end{array}$ & $\begin{array}{l}\text { Monounsaturated } \\
\text { alkyl esters / \% }\end{array}$ & $\begin{array}{c}\text { Polyunsaturated } \\
\text { alkyl esters / \% }\end{array}$ & Reference \\
\hline Crude palm oil & 25.70 & 50.6 & 40.1 & 9.21 & 31 \\
\hline $\mathrm{RBD}^{\mathrm{a}}$ palm oil & 9.24 & 44.4 & 43.4 & 12.2 & 67 \\
\hline Soy oil & 1.3 & 15.3 & 25.6 & 59.1 & 58 \\
\hline Castor oil & 3.18 & 3.49 & 87.86 & 6.72 & 60 \\
\hline Jatropha oil & 3.95 & 21.1 & 44.5 & 34.4 & 67,68 \\
\hline Sunflower oil & 0.8 & 11.1 & 25.6 & 63.3 & 58 \\
\hline High oleic sunflower oil & 1.2 & 9.3 & 62.9 & 27.6 & 58 \\
\hline Olive oil & 3.3 & 15.7 & 76.0 & 8.4 & 58 \\
\hline Groundnut oil & 2.0 & 15.6 & 55.7 & 28.7 & 58 \\
\hline Corn oil & 1.2 & 8.0 & 66.4 & 25.3 & 58 \\
\hline Pongamia oil & 2.54 & 16.0 & 72.2 & 11.8 & 68 \\
\hline Rapeseed oil & 9.1 & 9.66 & 61.8 & 29.02 & 30 \\
\hline Beef tallow oil & 1.2 & 41.11 & 46.69 & 9.14 & 30 \\
\hline
\end{tabular}

${ }^{\mathrm{a} R B D}$ : refined, bleached and deodorized. 
value and the oxidative stability of soy oil methyl esters were improved enough to satisfy EN 14214 specifications after blending with canola oil, palm oil or sunflower oil methyl esters. The cold filter plugging point of palm oil methyl esters was also improved through blending with canola oil, soybean oil and sunflower oil methyl esters.

Sarin et al. ${ }^{60}$ examined blends of jatropha and palm biodiesel in order to study their physicochemical properties and achieve an optimal mix in terms of cold flow properties and oxidative stability. The authors found that jatropha oil biodiesel has poor oxidation stability with good low temperature properties. On the other hand, palm oil biodiesel has good oxidative stability but poor low temperature properties. The combination of jatropha oil and palm oil gave an additive effect to these two critical properties of biodiesel.

Zuleta et al. ${ }^{61}$ evaluated the oxidative stability and coldfilter plugging point (CFPP) of binary blends of biodiesel from castor-jatropha, palm-castor and palm-sacha inchi for the ratios $(\mathrm{m} / \mathrm{m}) 25: 75,50: 50$ and $75: 25$. Oxidative stability was evaluated following the EN 14112 standard. The best biodiesel blend was castor-jatropha at a 75:25 ratio. This blend achieved an induction time of $7.56 \mathrm{~h}$ and CFPP of $-12{ }^{\circ} \mathrm{C}$. According to the authors, this is explained by this blend having a high content of monounsaturated methyl esters and a low content of saturated and polyunsaturated methyl esters.

\section{Effect of Antioxidants on the Oxidative Stability}

Oxidation may be interrupted by several kinds of antioxidants which can react with either chain-carrying peroxyl radicals or the alkyl radical intermediates. ${ }^{6}$ The first class of antioxidants $(\mathrm{AH})$, named primary antioxidants, ${ }^{62}$ includes hindered phenols such as butylated hydroxyanisole, butylated hydroxytoluene and a-tocopherol. To be effective, these compounds must compete with the unsaturated lipid substrate which is normally present in the highest concentration. The second class of antioxidants $\left(\mathrm{Q}^{*}\right)$, named secondary antioxidants, ${ }^{62}$ includes quinones such as ubiquinone and a-tocopherolquinone which must compete with $\mathrm{O}_{2}$ in a fast reaction. These compounds may therefore only be active in biological systems in which the oxygen content is relatively low.

In the presence of trace amounts of transition metals, hydroperoxides are readily decomposed to form the alkoxyl radical intermediates $\left(\mathrm{RO}^{*}\right)$ and $\left(\mathrm{ROO}^{*}\right)$, which can effectively propagate the free radical chain (Figure 9).

The catalytic effect of metals is greatly enhanced in methyl linolenate because linolenate hydroperoxides are much more

$$
\begin{aligned}
& \mathrm{ROOH}+\mathrm{M}^{\mathrm{n}} \longrightarrow \mathrm{RO}^{\cdot}+\mathrm{OH}^{\bullet}+\mathrm{M}^{\mathrm{n}+1} \\
& \mathrm{ROOH}+\mathrm{M}^{\mathrm{n}+1} \longrightarrow \mathrm{ROO}^{\cdot}+\mathrm{H}^{+}+\mathrm{M}^{\mathrm{n}}
\end{aligned}
$$

Figure 9. Formation of hidroperoxides for reaction with transition metals.

readily decomposed than linoleate hydroperoxides. ${ }^{63} \mathrm{In}$ the presence of metals, the activity of free radical-acceptor antioxidants is also significantly diminished because their reactivity towards RO* is only one order of magnitude higher than that of the unsaturated lipids. ${ }^{64}$ For these reasons, phenolic and other antioxidants are much less effective in inhibiting the oxidation of linolenate-containing oils, such as soy bean and rapeseed oils, than that of linoleate-containing oils, such as sunflower and safflower oils.

Metal chelators act as preventive antioxidants by complexing metal ions and thus retarding free radical formation and hydroperoxide decomposition. Because linolenate hydroperoxides are so readily decomposed in the presence of metal catalysts, metal chelators are particularly effective in preventing linolenate oxidation. Metal chelators are thus more effective than phenolic antioxidants at controlling the oxidative deterioration of soy bean oil that contains linolenate. ${ }^{38}$ Antioxidant synergism is a process by which the antioxidant effect of multi-component systems is reinforced. Significant synergism is generally observed between free radical acceptor antioxidants and metal chelators. Antioxidant synergism is particularly important between natural tocopherols found in soy bean oil and metal chelators, such as citric acid, which are essential to ensure oxidative stability. ${ }^{38}$ Another type of antioxidant synergism is produced by reducing agents such as ascorbic acid. ${ }^{65}$

Natural antioxidants, such as carotenoids, can be found in biodiesel from the oils and fats from which the biodiesel is obtained, but their concentrations and effects vary depending on the transesterification process and the purification steps employed. ${ }^{5,66}$ Synthetic antioxidants are often more effective than natural ones. Antioxidants that have been studied for addition to biodiesel are: butylated hydroxyanisole (BHA), butylated hydroxytoluene (BHT), tertiary butylhydroquinone (TBHQ), propyl gallate (PG) and ascorbyl palmitate (AP), among others.

The effectiveness of antioxidants in biodiesel depends on the type of biodiesel, the concentration employed and the presence of metals. ${ }^{31,32,62,66,68,69}$ Some authors report that BHA and BHT have almost the same effect on the oxidative stability of biodiesel made from rapeseed and tallow. ${ }^{70}$ In contrast, others report that although pyrogallol, PG and TBHQ can significantly improve the stability of biodiesel made from rapeseed oil, waste frying oil and beef fat, BHT does not cause any significant effect. ${ }^{30}$ 
Studies developed on the effectiveness of antioxidants in the presence of transition metals such as copper, iron, nickel, cobalt, titanium and manganese, ${ }^{35,69,71}$ show how the effectiveness of antioxidants decreases depending on the type of metal. Sarin et al. ${ }^{68}$ reported that it is necessary to add a minimal amount of $650 \mathrm{ppm}$ of BHT to achieve an induction time of $6 \mathrm{~h}$ in pongamia oil biodiesel contaminated with iron and nickel, and a minimum of $750 \mathrm{ppm}$ of BHT in the same biodiesel contaminated with manganese. They also report that 950 and $1050 \mathrm{ppm}$ of BHT need to be added to pongamia oil biodiesel contaminated with cobalt and copper, respectively, to achieve the $6 \mathrm{~h}$ induction time.

The oxidation stability of biodiesel is regulated by international standards utilizing what is known as the induction time. Because in practice there are few biodiesels that meet the regulated minimum values $(6 \mathrm{~h}$ in the EN 14214, and $3 \mathrm{~h}$ in the ASTM D6751), it is necessary to add antioxidants to enable them to meet the standards. Table 4 shows some minimum concentrations that must be added to different types of biodiesel to meet the induction time required by EN 14214.

Table 4. Antioxidant concentration to achieve the induction time required by EN14214

\begin{tabular}{lccc}
\hline Biodiesel & Antioxidants & $\begin{array}{c}\text { Concentration / } \\
\text { ppm }\end{array}$ & Reference \\
\hline Jatropha (methyl ester) & BHT & 200 & 65 \\
Soy (ethyl ester) & BHT & 8000 & 76 \\
Soy (ethyl ester) & TBHQ & $7000-8000$ & 76 \\
Soy (methyl ester) & BHT & 1000 & 32 \\
Soy (methyl esters) & BHA & 1000 & 32 \\
Soy (methyl ester) & TBHQ & 500 & 32 \\
Soy (methyl ester) & PG & 250 & 32 \\
Cotton (methyl ester) & BHT & 250 & 32 \\
Cotton (methyl ester) & BHA & 250 & 32 \\
Palm (methyl ester) & not required & not required & \\
\hline
\end{tabular}

As seen in Table 4, not all antioxidants have the same effect on the different types of biodiesels evaluated. This implies the need to experimentally determine the type and concentration of antioxidant needed to achieve the induction times required by international standards.

\section{Corrosive Effect of Biodiesel on Metallic Materials Used in Automotive Parts and Storage Structures}

Biodiesel as an alternative fuel has some technical advantages over conventional diesel, but it tends to be more corrosive. The corrosive behavior of biodiesel can be caused by free water and free fatty acids present in the fuel. ${ }^{73,74}$ Free fatty acids may exist as a result of incomplete transesterification reactions. ${ }^{6}$ Compared with diesel, biodiesel is more prone to absorb water. This is because the esters in this biofuel exhibit some hygroscopic properties, thereby increasing the water content. ${ }^{73}$ The water tends to condense on the metal surface causing corrosion and deterioration of the material. The corrosion reactions between a non-noble metal and water are shown in Figure 10.

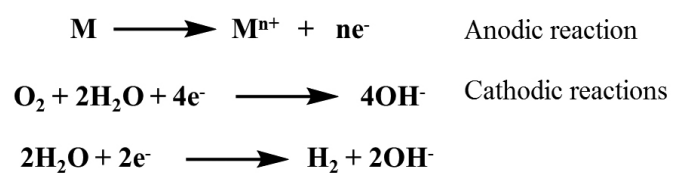

Figure 10. Corrosion reactions between a non-noble metal and water.

During the oxidation process of biodiesel, methyl esters of fatty acids form a radical which quickly links with oxygen in the air, ${ }^{67}$ forming volatile products such as aldehydes, ketones and lactones, ${ }^{75}$ and formic, acetic, propionic and caproic acids. ${ }^{76}$ The autoxidation of biodiesel can increase its corrosive and fuel degradation properties. ${ }^{74}$ So far there has been little research on the corrosion of different metals exposed to biodiesel, ${ }^{53,77}$ but it has been found that materials such as copper, aluminum, zinc, brass and bronze are not compatible with this fuel ${ }^{78}$ Fazal et al. ${ }^{74}$ performed static immersion tests to investigate the corrosion of copper, aluminum and stainless steel 316 exposed to palm oil biodiesel, using conventional diesel for comparison. Initially, both fuels were free of water, but after testing, it was found that the water content in the biodiesel was much greater due to its more hygroscopic nature..$^{74}$

\subsection{Metallic corrosion mechanisms and the formation of} corrosion products in biodiesel

Currently there are no reports about the corrosion mechanisms in biodiesel, but some authors have investigated the corrosion products and metal compounds generated in biodiesel exposed to metals at different temperatures. A recent study found pitting corrosion in copper specimens exposed to biodiesel at $80{ }^{\circ} \mathrm{C}$. The morphology of the pits and the mechanism of the bites seem to depend on the relative concentrations of positive and negative ions. ${ }^{74}$ Copper in the presence of oxygen forms rich-layers of $\mathrm{CuO} / \mathrm{CuCO}_{3}$ (outer layer), followed by $\mathrm{Cu}_{2} \mathrm{O}$ (inner layer). ${ }^{79}$ Similar oxide layers on copper seem to occur in $\mathrm{O}_{2}$-rich biodiesel. The pits on the copper surface exposed to the biodiesel appear to be formed by the substitution of 
oxygen ions from $\mathrm{Cu}_{2} \mathrm{O}$ through the destruction of the $\mathrm{CuO}$ layer. ${ }^{74}$ Another study found that at room temperature, an oxide layer was formed on the surface of copper exposed to $\mathrm{B} 100$, which seemed to be copper carbonate $\left(\mathrm{CuCO}_{3}\right)$. At $60^{\circ} \mathrm{C}$, the layer formed was copper oxide $(\mathrm{CuO})$, which occurred as a result of an increased quantity of dissolved oxygen in the biodiesel. ${ }^{6}$

During the processing, storage or oxidation of biodiesel, different organic acids can be formed. The corrosion of copper in organic acids has a complex reaction mechanism which has been studied mainly in atmospheric conditions. ${ }^{80,81}$ Figure 11 exhibits the main reactions that could take part in the corrosion of copper exposed to carboxyl acids.

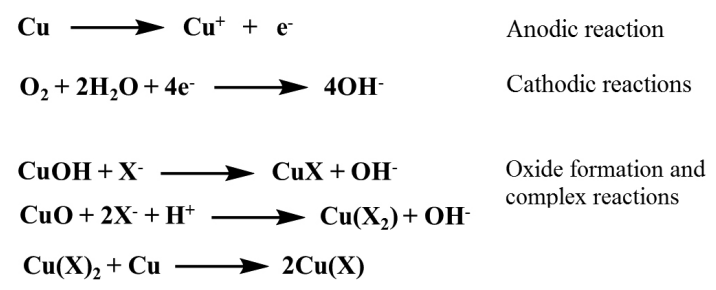

Figure 11. Corrosion mechanism of copper exposed to carboxylic acids..$^{80,81}$

According to Figure 11, the mechanism that arises for copper corrosion in carboxylic acids is the proton and ligand-induced dissolution of this metal. A prerequisite for this mechanism is the presence of a thin aqueous adlayer $\left(1 \mu \mathrm{g} \mathrm{cm}^{-2}\right),{ }^{81}$ which produces hydroxyl bonds over the copper oxide. The hydroxyl bonds have properties for ion exchange and can be replaced by ions present in the aqueous layer as protons $\left(\mathrm{H}^{+}\right)$and carboxyl ions $\left(\mathrm{X}^{-}\right)$. The formation of copper-carboxilate complexes can occur by autocatalytic reactions with pure copper or copper oxides. A similar reaction mechanism has been proposed for corrosion of zinc and nickel in organic acids. ${ }^{82}$

In the case of carbon steel exposed to biodiesel, different compounds detected by $\mathrm{X}$-ray diffractometry have been reported, such as $\mathrm{Fe}(\mathrm{OH})_{3}, \mathrm{Fe}_{2} \mathrm{O}_{2} \mathrm{CO}_{3}$ and $\mathrm{Fe}_{2} \mathrm{O}_{3}$, formed in the presence of water and oxygen. Energy dispersive $\mathrm{X}$-ray spectroscopy (EDS) analysis shows that the presence of oxygen in biodiesel increases with temperature. ${ }^{83}$ The reason why the $\mathrm{Fe}_{2} \mathrm{O}_{2} \mathrm{CO}_{3}$ chemical species is formed on the metal is the high level of water, $\mathrm{O}_{2}$ and $\mathrm{CO}_{2}$ absorbed from the air. ${ }^{83} \mathrm{Fe}_{2} \mathrm{O}_{2} \mathrm{CO}_{3}$ is the product of the reaction between $\mathrm{H}_{2} \mathrm{CO}_{3}$ and $\mathrm{FeO}(\mathrm{OH})$. The $\mathrm{FeO}(\mathrm{OH})$ is the final product of several redox reactions between iron, $\mathrm{O}_{2}$ and $\mathrm{H}_{2} \mathrm{O}^{84} \mathrm{H}_{2} \mathrm{CO}_{3}$ comes from the reaction of water with carbon dioxide absorbed from the air. Oxygenation of biodiesel can further increase the corrosion of carbon steel. ${ }^{83}$ It has been reported that the resistance of the biodiesel to oxygenation is due to its fatty components. The hygroscopic property of biodiesel seems to increase with the increase of the temperature. ${ }^{6}$

$\mathrm{KOH}$ or $\mathrm{NaOH}$ compounds may be present in biodiesel from the catalyst processes. When immersed in an alkaline medium containing $\mathrm{KOH}$ or $\mathrm{NaOH}$, aluminum can suffer anodic dissolution releasing $\mathrm{AlO}^{-}$and $\mathrm{Al}(\mathrm{OH})^{-}{ }_{4}$ ions. This aluminum species tends to form a passive layer of $\mathrm{Al}(\mathrm{OH})_{3}{ }^{85}$ through the reduction of electrolytes such as water, ${ }^{86}$ or methanol, ${ }^{87}$ causing hydrogen evolution in the process. ${ }^{87,88}$ The exposure of different metals to biodiesel and the presence of dissolved oxygen can increase the corrosivity of the fuel. Different factors may be involved in the corrosion processes in biodiesel, such as changes in the acid values, increases in water content, the presence of oxidation products, the presence of metal species and changes in the structural characteristics of the biodiesel. ${ }^{82}$

\subsection{Techniques for studying corrosion in metallic materials}

In order to analyze the behavior of metallic materials in biodiesel and fuel mixtures, many studies have used immersion tests. ${ }^{6,9,74}$ These studies aim to accelerate material deterioration. Simulating the conditions of interest, they consist of the total immersion of the samples in a reactorrecipient containing the biodiesel ${ }^{89} \mathrm{Fazal}$ et al. ${ }^{74}$ carried out immersion tests with palm oil biodiesel (B100) and conventional diesel at $80{ }^{\circ} \mathrm{C}$ over $1200 \mathrm{~h}$ to compare the corrosion behavior of aluminum, copper and stainless steel. At the end of the test, the corrosion phenomenon was studied by mass loss, corrosion rate and changes in the exposed metal surface. The corrosion rates obtained for copper, aluminum and stainless steel were $0.586,0.202$ and 0.015 mpy, respectively. It was observed that the corrosion rate of copper in biodiesel increased with immersion time, while for aluminum it decreased slightly. Stainless steel did not exhibit substantial corrosion in biodiesel. ${ }^{74}$

Kaul et al. ${ }^{9}$ used the static immersion test for 300 days at room temperature to assess the deterioration of metallic pistons immersed in different biodiesels produced from jatropha oil, karanja oil, mahua oil and salvadora oil. These studies found that biodiesels from jatropha oil and salvadora oil were the most aggressive for both ferrous and non-ferrous metals.

Since corrosion is an electrochemical process, metal corrosion in biofuels that contain only a small quantity of water can be assessed by electrochemical test methods. Electrochemical methods allow short time results to be obtained and can explain the corrosion processes. Polarization and electrochemical impedance spectroscopy (EIS) have commonly used electrochemical techniques to evaluate the resistance of metallic materials to biodiesel. ${ }^{73,90}$ 
Dáaz-Ballot et al..$^{90}$ evaluated the corrosion of aluminum exposed to biodiesel containing different levels of contaminants and impurities such as $\mathrm{KOH}$ and $\mathrm{NaOH}$. The authors used conventional electrochemical techniques like the measurement of open circuit potential, EIS and anodic polarization..$^{90}$ It was found that the open circuit potential $\left(\mathrm{E}_{\text {ocp }}\right)$ of aluminum immersed in biodiesel, after several washing cycles, was slightly negative and increased with time. This behavior suggests a decreased surface activity of the aluminum due to the formation of a layer of corrosion products that acts as a passive film. During the first cycles of washing, $\mathrm{E}_{\text {ocp }}$ exhibited very negative values, below $-600 \mathrm{mV}$, suggesting that the aluminum surface reacts with species present in the biodiesel forming a passive layer on the metal surface. However, in further washing cycles, $\mathrm{E}_{\text {ocp }}$ shifted to more positive values, suggesting a decrease in electrochemical activity. These results suggest that the study of aluminum corrosion in biodiesel employing electrochemical techniques can be used as a quantitative indicator of the corrosivity of this fuel.

Tsuchiya et al. ${ }^{76}$ investigated the corrosion behavior of steel immersed in biodiesel mixed with different acids produced during the oxidation of the fuel. The authors showed that corrosion of this metal was caused by the fatty acids present in the fuel after its oxidation. ${ }^{76}$ Among the organic acids derived from the oxidation of FAME (fatty acid methyl ester), it is common to find formic, propionic and acetic acid. Oleic and linoleic acids are present in the raw material as free acids. Metallic materials exposed to a fuel mixed with $30 \mathrm{ppm}$ of acetic acid, $30 \mathrm{ppm}$ of butyric acid, and $125 \mathrm{ppm}$ of caproic acid or $155 \mathrm{ppm}$ of caprylic acid showed pitting corrosion as the main form of deterioration. ${ }^{76}$ No pitting corrosion was observed when formic acid was added to the fuel. However, it is suggested that the concentration of this acid must be regulated in the same way as the concentration of acetic acid since the corrosive action of formic acid is stronger than acetic acid. This study found that in the fuel, the concentration of corrosive acids generated by the oxidation of FAME, such as formic, acetic and propionic acids, can be tolerated up to a limit of $30 \mathrm{ppm}$ before pitting begins.

The results of corrosion tests are established from the variations of the surface of the material, the material itself and the corrosive agent. Furthermore, it is often desirable to know the composition and quality of the corrosion products. Analysis of the metal surface with optical and stereoscopic microscopy determines the way in which corrosion products are deposited on the surface. It is important to deduce whether the corrosion proceeds without the formation of solid products or if the produced damage on the surface is in the form of cracks, pits or a similar type of deformation. It should also be noted whether the attack is uniform or localized. ${ }^{91}$ The electron microscopy technique allows the observation of the microstructure of all kinds of samples with a resolution that exceeds that of optical microscopy. This technique has been widely used to analyze the corrosion products of certain metallic materials immersed in biodiesel. . $33,74^{2}$

Using optical microscopy, Fazal et al. ${ }^{74}$ observed the surface of copper and aluminum samples and saw pitting corrosion after exposure to biodiesel. Through this technique, it was possible to measure the depth of the pits using equation 3 :

Pit density $=\frac{\sum_{i 1}^{n} l_{i}}{L} \times 100$

where $n$ is the number of wells located on a straight line drawn horizontally from one end of the photo-optic to another, $l$ is the length of a pit that overlaps the straight line and $L$ is the total length of the straight line. Using biodiesel, the average depth for copper was $80 \%$ and for aluminum it was $18 \%$, while with diesel depths of 54 and $10 \%$ were obtained, respectively. Unfortunately, there are no pit depth data for other active metals exposed to biodiesel for comparison. The scanning electron microscopy technique (SEM) was used to observe in greater detail the damage of the surface of metals exposed to biodiesel. SEM images were taken at $100 \times$ and $2000 \times$ magnification. A greater number of pits were found in the copper than in other metals, and the size and distribution of these pits varied depending on the concentration of negative and positive ions. The pits were probably formed by the replacement of oxygen ions from the $\mathrm{Cu}_{2} \mathrm{O}$ layer through the destruction of the $\mathrm{CuO}$ layer. Analysis using energy dispersive $\mathrm{X}$-ray spectroscopy (EDS) showed that the oxide layer of copper and aluminum samples immersed in biodiesel contained a high percentage of carbon and oxygen.

\section{Effects of Biodiesel on the Degradation of Polymeric Materials Used in Automotive Parts and Storage Structures}

As well as metallic materials, biodiesel can also affect some polymers and elastomers. ${ }^{92,93}$ To analyze the behavior of polymeric materials exposed to mixtures of fuels, many studies have used continuous immersion tests. ${ }^{94,95}$ The results of polymer degradation are established from structural changes, mass gain, mass loss, dimensional changes and a variation of mechanical properties such as hardness, tensile strength, bending, etc. All of these changes and variations take into account that the absorption 
of the fuel and the extraction of soluble components such as plasticizers and additives are different for each type of elastomer. ${ }^{95}$

Haseeb et al..$^{94}$ investigated the impact of palm oil biodiesel on the degradation of nitrile rubber (NBR), polychloroprene and Viton Type A, using static immersion tests for B0 (diesel), B10 (10\% biodiesel) and B100 (100\% biodiesel) at room temperature and $50{ }^{\circ} \mathrm{C}$ for $500 \mathrm{~h}$. After testing, the degradation of these elastomers was analyzed by mass, volume, hardness, tensile strength and elongation change. The authors found that after immersion in biodiesel, tensile strength, elongation and hardness of nitrile rubber (NBR) and polychloroprene were significantly diminished, while the changes in Viton A were negligible..$^{94}$ The mass and volume of the NBR exposed to biodiesel increased by 20.2 and $11.48 \%$, respectively, due to the spread of the fuel into the material at high temperature. The mass and volume for polychloroprene were reduced by 17.9 and $19.20 \%$, respectively. The tensile stress and elongation of NBR before immersion were $10.4 \mathrm{MPa}$ and $750 \%$, respectively, while after exposure to biodiesel, they decreased to $8.7 \mathrm{MPa}$ and $646 \%$, respectively. A decrease in tensile strength and length from 3.9 MPa and 225.6\% to $2.3 \mathrm{MPa}$ and $216.6 \%$, respectively, were also observed.

Bessee et al..$^{96}$ investigated the effect of mixtures of diesel and soybean oil biodiesel on the tensile strength, elongation, hardness, change in volume and change in mass of several common elastomers. They found that nitrile rubber, nylon 6.6 and high-density polypropylene exposed to biodiesel at $51.7{ }^{\circ} \mathrm{C}$ for $694 \mathrm{~h}$ showed changes in the mechanical properties. In contrast, Teflon, Viton 401-C, and Viton GFLT were not affected by the fuel mixture. It has been reported that palm oil biodiesel blended with diesel (B10) causes the swelling of hydrogenated nitrile butadiene rubber (HNBR) and changes in elongation, which increase with immersion time. ${ }^{95}$

Maru et al. ${ }^{92}$ investigated the interaction between soybean and sunflower biodiesels with high density polyethylene (HDPE) through static immersion tests at a temperature of $60{ }^{\circ} \mathrm{C}$ during 125 days. Figure 12 shows the HDPE weight variation after 125 days of immersion in diesel and in two different biodiesels. The weight gain of

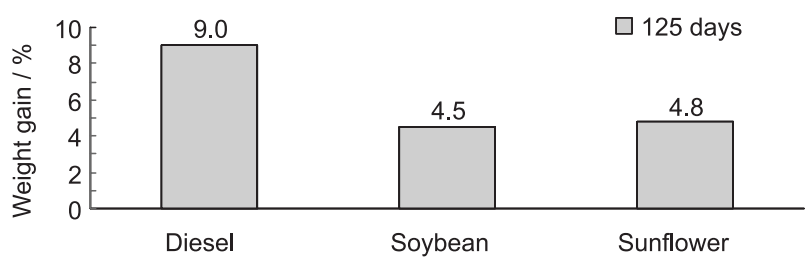

Figure 12. Weight gain of HDPE after immersion in diesel and soybean and sunflower biodiesel at $60{ }^{\circ} \mathrm{C} .{ }^{92}$
HDPE after immersion was slightly greater in diesel than in biodiesels and it was attributed to the fuel absorption processes. According to this result, HDPE is compatible with soybean and sunflower biodiesels.

Haseeb et al. ${ }^{97}$ compared the change in physical properties of some polymeric materials such as ethylene propylene diene monomer (EPDM), silicone rubber (SR), polychloroprene (CR), polytetrafluroethylene (PTFE) and nitrile rubber (NBR) after $1000 \mathrm{~h}$ of immersion in different mixtures of palm biodiesel at $25^{\circ} \mathrm{C}$. The authors analyzed the changes in weight, tensile strength and hardness of the materials. ${ }^{97}$ Figure 13 shows the weight variation of the materials found by the authors. EPDM and SR were more affected by diesel than biodiesel, while CR and NBR were more strongly affected by biodiesel. PTFE was practically not affected by the fuels.

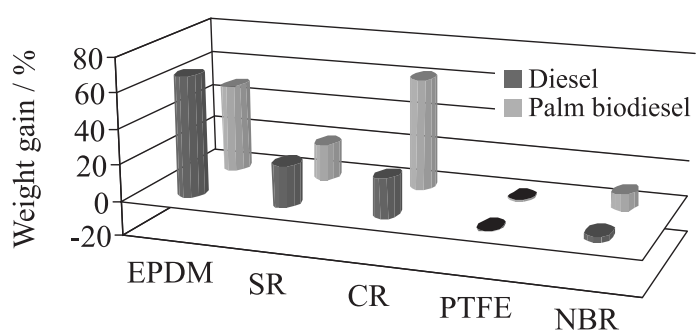

Figure 13. Weight variation of different elastomer materials after $1000 \mathrm{~h}$ of immersion in diesel and palm biodiesel at $25^{\circ} \mathrm{C} .{ }^{97}$

The tensile strength and hardness of EPDM and CR decreased after immersion in both diesel and biodiesel. On the other hand, SR, PTFE and NBR materials did not exhibit significant changes in their mechanical properties.

Terry et al. ${ }^{98}$ analyzed the impact of biodiesel blends on five elastomeric materials used in the automotive fuel system. The materials were: NO674-70 Sulfur-cured acrylonitrile, butadiene nitrile rubber (medium acrylonitrile content of 30-35\%), NB104-75 peroxide cured acrylonitrile butadiene nitrile rubber (higher acrylonitrile content), KB162-80 hydrogenated nitrile polymer, VB153-75 fluorocarbon polymer (67\% fluorine content) and V1164-75 fluorocarbon polymer ( $66 \%$ fluorine content). Specimens of these polymers were exposed in the test fuels at $60{ }^{\circ} \mathrm{C}$ for $1000 \mathrm{~h}$. The authors analyzed the impact of the biodiesel blends on some physical properties such as volume swell, hardness, dimensional changes, compression and tensile properties. ${ }^{98}$ They found that fluorocarbon elastomers of medium to high fluorine content are compatible with biodiesel blends at a concentration of $20 \%$ or less. The other materials tested in biodiesel blends exhibited good resistance to changes in physical properties, but exceeded the typically acceptable levels of degradation in one or more tests. 


\subsection{Techniques for studying the degradation of polymeric materials}

DSC has become the most commonly used thermal analysis technique to evaluate the degradation of polymers. This technique measures endothermic and exothermic transitions as a function of temperature. ${ }^{7}$ From the results of the thermogravimetric analysis (TGA), the maximum degradation temperature of a tested polymer sample can be obtained. ${ }^{99}$ Fourier transform infrared spectroscopy (FTIR) is used to determine structural and chemical changes in polymeric materials associated with degradation caused by immersion in media such as biodiesel. The SEM and FTIR techniques have been used to study surface changes as well as chemical and structural changes in polymeric and elastomeric materials in contact with biodiesel. ${ }^{94,95}$

Haseeb et al. ${ }^{94}$ observed changes in the surface of different elastomers exposed to biodiesel for $500 \mathrm{~h}$. SEM images of NBR showed a higher number of wells and fissures than polychloroprene and flour-Viton A after immersion in biodiesel. The formation of cracks and microcracks in the elastomers exposed to biodiesel can be attributed to the breakdown or crosslinking of macromolecule chains and the introduction of oxygen polar groups. Using FTIR, significant structural changes were observed in NBR and polychloroprene after exposure to biodiesel. In contrast, in flour-Viton A, there were no significant changes. The FTIR spectrum of NBR before immersion showed absorption bands in the region of $2850-2938 \mathrm{~cm}^{-1}$ corresponding to the stretching of the $=\mathrm{CH}$ and $-\mathrm{CH}_{2}$ groups, and a band at $967 \mathrm{~cm}^{-1}$ attributed to the vinyl group $\mathrm{CH}=\mathrm{CH}_{2}$. After immersion in biodiesel at $50{ }^{\circ} \mathrm{C}$, a new band appeared in the $1650 \mathrm{~cm}^{-1}$ region, possibly associated with the generation of a new $\mathrm{C}-\mathrm{C}$ bond.

Maru et al..$^{92}$ used different characterization techniques such as optical microscopy and the Raman and Fourier transform infrared (FTIR) spectroscopies to characterize the effects of soybean and sunflower biodiesels on HDPE. The FTIR spectrum of HDPE revealed a new peak around $1740 \mathrm{~cm}^{-1}$ which is assigned to the $\mathrm{C}=\mathrm{O}$ group present in the biodiesel. The presence of a new band associated to different bonds could be related to the structural transformation of the polymeric material after interaction with the biodiesel.

\section{Conclusions}

Oxidative stability is a factor of major importance in biodiesel production since it can drastically affect the quality of biofuels and their performance in compression ignition engines (diesel type engines). This is the reason why international regulatory agencies, biodiesel producers, engine manufacturing companies, research centers and universities around the world have been working hard to investigate the oxidation of biodiesel and find alternatives to avoid it.

As the oxidative stability of biodiesel depends strongly on the alkyl chain that constitutes it, in practice the range of natural fats and oils from which this biofuel can be produced is limited. This should be taken into account when considering the establishment of companies or industrial chains focused on the production of biodiesel from specific oilseed plant species, animal fat or lipids (such as microalgae oil). If a biodiesel from a particular fat or oil does not meet the oxidative stability requirements, specific amounts of antioxidants will need to be added in order to increase the induction time. Such a necessity leads to increased biofuel production costs, which are reflected in the price paid by the consumer.

Because to some extent all biodiesels are susceptible to oxidation, it is necessary to control the external factors that encourage this phenomenon, such as the presence of oxygen, light and exposure to contaminated substances (metals and free radicals). Measures must therefore be implemented to ensure minimal loss of biodiesel quality so that the materials that constitute the storage and handling of biofuel systems and automotive parts remain unaffected.

Using biodiesel has various disadvantages, mainly regarding its compatibility with different materials used in automotive parts or in storage containers. Oxidation reactions experienced by biodiesel promote the generation of acidic species that attack automotive part materials through corrosion and degradation reactions, thereby threatening the integrity of the vehicle or the structure. Corrosion is one of the most important issues when looking at the compatibility of materials with biodiesel. Metallic materials such as bronze, brass, copper, aluminum, tin and zinc may oxidize biodiesel and create sediments. Due to their functionality as a solvent, some polymeric materials, such as elastomers, can be dissolved by biodiesel. Consequently, the aromatic compounds of elastomers, as well as the additives intended to prevent hardening and cracking, are leached.

In conclusion, it is of great importance to evaluate the corrosion behavior of biodiesel and the stability of the materials that are in permanent contact with the fuel prior to its general use in engines. Studies must also to be oriented towards searching for ways to decrease material deterioration. 


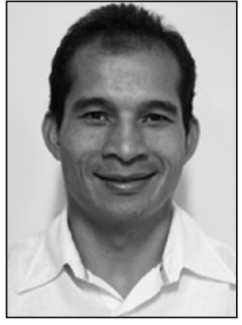

Jorge A. Calderon is an Associated Professor of the Department of Materials of the University of Antioquia (Medellín, Colombia). He is also a researcher at the Centre for Research, Innovation and Development of Materials (CIDEMAT) of the University of Antioquia (Medellin, Colombia). He wrote his PhD thesis in Science in Materials Engineer at the Federal University of the Rio de Janeiro (Rio de Janeiro, Brazil) in 2003. He was a Visiting Scientist at the Laboratoire Interfases et Systemes Electrochimiques of the Universite Pierre et Marie Curie (Paris, France), Laboratório de Materiais Eletroativos of the Universidade de São Paulo (São Paulo, Brazil) and at the Laboratório de Ensaios Não Destrutivos, Corrosão e Soldagem (LNDC/COPPE) of the Universidade Federal do Rio de Janeiro (Rio de Janeiro, Brazil). Dr. Calderon's research is in several areas of electrochemistry and material science. His current work is focused on electrochemical materials and corrosion in biofuels. He has authored over 50 indexed publications, including several book chapters.

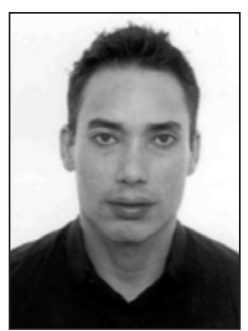

Luis Alberto Rios Dr. rer. nat., RWTH Aachen University (Germany, 2003); MSc Chemical Sciences, Universidad de Antioquia (Colombia, 1998); Chemical Engineer, Universidad de Antioquia (Colombia, 1995). He is a Professor of Chemical Engineering in the Universidad de Antioquia since 2003 to date, being the Director of the Research Group Applied Physical-chemical Processes, Universidad de Antioquia since 2003 to date. His research areas are oleochemistry, biofuels, polymers from renewable sources and valorization of natural products. He is author of 45 international publications, three books and two international patents.

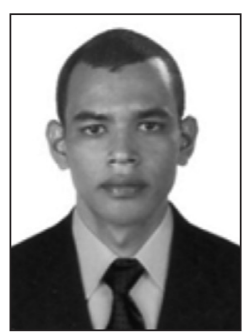

Ernesto Camilo Zuleta Suarez is an Agroindustrial Engineering (Universidad Popular del Cesar, Colombia, 2007). He has developed research projects related to the production of biodiesel from natural oils since 2008 to date. In this field, he has worked on the purification of oils, studied the use of homogeneous and heterogeneous catalysts, the use of various alcohols such as ethanol and methanol, and the evaluation of properties such as oxidative stability, low temperature flow and viscosity of the biodiesel. Currently culminates his MSc Engineering studies in the area of oleochemistry (Universidad de Antioquia, Medellín, Colombia).

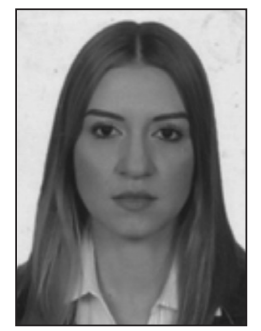

Libia M. Baena completed her MSc in 2010 at the Research Center of Innovation and Development of Materials (CIDEMAT) of the University of Antioquia (Medellin, Colombia). Her work is focused on the evaluation of aggressiveness and corrosion of biofuels and biofuels blends. Currently, she working for her PhD in Engineering at the CIDEMAT in the University of Antioquia, where she researches on aggressiveness of palm and jatropha biodiesel on metal and polymer automotive parts.

\section{Acknowledgments}

Authors thank COLCIENCIAS by support in the project 1115-489-25421 and University of Antioquia by support in "Sostenibilidad 2013-2014"

\section{References}

1. Knothe, G.; Prog. Energy Combust. Sci. 2010, 36, 364.

2. Scrimgeour, C. In Bailey's Industrial Oil and Fat Products, vol. 1; Shahidi, F., ed.; Wiley-Interscience: New York, NY, USA, 2005, ch. 1

3. Schaich, K. M. In Bailey's Industrial Oil and Fat Products, vol. 1; Shahidi, F., Ed. Wiley-Interscience: New York, NY, USA, 2005, ch. 7

4. Kerr, J. A.; Chem. Rev. 1966, 66, 465.

5. Knothe, G.; Fuel Process. Technol. 2007, 88, 669.

6. Haseeb, A.; Masjuki, H.; Ann, L.; Fazal, M.; Fuel Process. Technol. 2010, 91, 329.

7. Brown, M. E.; Gallagher, P. K. In Handbook of Thermal Analysis and Calorimetry, Michael, E. B.; Patrick, K. G., eds.; Elsevier Science B.V.: Vol. 5, 2008, ch. 1.

8. Tyson, K. S.; Biodiesel Handling and Use Guidelines; DIANE Publishing Co.: Darby, PA, USA, 2009.

9. Kaul, S.; Saxena, R. C.; Kumar, A.; Negi, M. S.; Bhatnagar, A. K.; Goyal, H. B.; Gupta, A. K.; Fuel Process. Technol. 2007, 88, 303.

10. Xie, Q. G.; Taweepreda, W.; Musikavong, C.; Suksaroj, C.; Water Sci. Technol. 2012, 65, 1158.

11. Koontz, K.; Commercialization of Biodiesel: Establishment of Engine Warranties; University of Idaho National Center for Advanced Transportation Technology: Moscow, Russia, 1994, p. 107. 
12. Fang, H.; McCormick, R.; SAE Technical Paper 2006-01-3300, 2006, DOI 10.4271/2006-01-3300.

13. Lin, C.-Y.; Chiu, C.-C.; Energy Fuels 2009, 23, 3285.

14. Bouaid, A.; Martinez, M.; Aracil, J.; Fuel 2007, 86, 2596.

15. Das, L. M.; Bora, D. K.; Pradhan, S.; Naik, M. K.; Naik, S. N.; Fuel 2009, 88, 2315.

16. McCormick, R. L.; Westbrook, S. R.; Energy Fuels 2009, 24 , 690; Canakci, M.; Monyem, A.; Van, G. J.; T. ASAE 1999, 42, 1565.

17. Mittelbach, M.; Gangl, S.; J. Am. Oil Chem. Soc. 2001, 78, 573.

18. McCormick, R. L.; Ratcliff, M.; Moens, L.; Lawrence, R.; Fuel Process. Technol. 2007, 88, 651.

9. Lin, C.-Y.; Lin, H.-A.; Hung, L.-B.; Fuel 2006, 85, 1743.

20. Leung, D. Y. C.; Koo, B. C. P.; Guo, Y.; Bioresour. Technol. 2006, 97, 250.

21. Conceicao, M. M.; Fernandes, V. J.; Araujo, A. S.; Farias, M. F.; Santos, I. M. G.; Souza, A. G.; Energy Fuels 2007, 21, 1522.

22. Moser, B.; J. Am. Oil Chem. Soc. 2009, 86, 699.

23. ASTM D 5554: Standard Test Method for Determination of the Iodine Value of Fats and Oils; ASTM International: West Conshohocken, PA, USA, 2006.

24. ASTM D3703: Standard Test Method for Hydroperoxide Number of Aviation Turbine Fuels, Gasoline and Diesel Fuels; ASTM International: West Conshohocken, PA, USA, 2007.

25. ASTM D664: Standard Test Method for Acid Number of Petroleum Products by Potentiometric Titration; ASTM International: West Conshohocken, PA, USA, 2009.

26. Shahidid, F.; Zhong, Y. In Bailey's Industrial Oil and Fat Products, vol. 1; Shahidi, F., ed.; Wiley-Interscience: New York, NY, USA, 2005, ch. 12.

27. Knothe, G.; J. Am. Oil Chem. Soc. 2002, 79, 847.

28. Dunn, R.; J. Am. Oil Chem. Soc. 2005, 82, 381.

29. Russin, T.; van de Voort, F.; Sedman, J.; J. Am. Oil Chem. Soc. 2003, 80, 635; Wang, Y.; Zhao, M.; Tang, S.; Song, K.; Han, X.; Ou, S.; J. Am. Oil Chem. Soc. 2010, 87, 483; Moser, B.; In Vitro Cell. Dev. Biol.- Plant 2009, 45, 229; Buchanan, E.; P. S. Afr. Sug. 1979, 1, 10.

30. Mittelbach, M.; Schober, S.; J. Am. Oil Chem. Soc. 2003, 80, 817.

31. Liang, Y. C.; May, C. Y.; Foon, C. S.; Ngan, M. A.; Hock, C. C.; Basiron, Y.; Fuel 2006, 85, 867.

32. Tang, H.; Wang, A.; Salley, S.; Ng, K.; J. Am. Oil Chem. Soc. 2008, 85, 373.

33. Dunn, R. O.; Fuel Process. Technol. 2005, 86, 1071.

34. Läubli, M.; Bruttel, P.; J. Am. Oil Chem. Soc. 1986, 63, 792.

35. Knothe, G.; Dunn, R.; J. Am. Oil Chem. Soc. 2003, 80, 1021.

36. Knothe, G.; Fuel Process. Technol. 2005, 86, 1059.

37. Lin, C.-Y.; Chiu, C.-C.; Energy Convers. Manage. 2010, 51, 1464.

38. Frankel, E. N.; Cooney, P. M.; Moser, H. A.; Cowan, J. C.; Evans, C. D.; Fette, Seifen, Anstrichmittel 1959, 61, 1036.
39. Waynick, J. A. Characterization of Biodiesel Oxidation and Oxidation Products; Southwest Research Institute: Golden, CO, USA, 2005.

40. Monyem, A.; Gerpen, J. H. V.; Canakci, M.; Appl. Eng. Agric. 2000, 16, 373.

41. Knothe, G.; Steidley, K. R.; Fuel 2005, 84, 1059; Conceição, M. M.; Candeia, R. A.; Dantas, H. J.; Soledade, L. E. B.; Fernandes, V. J.; Souza, A. G.; Energy Fuels 2005, 19, 2185.

42. Hancock, R. A.; Leeves, N. J.; Nicks, P. F.; Prog. Org. Coat. 1989, 17, 321.

43. Jain, S.; Sharma, M. P.; Fuel 2012, 102, 354.

44. Punta, C.; Rector, C. L.; Porter, N. A.; Chem. Res. Toxicol. 2005, $18,349$.

45. Jayed, M. H.; Masjuki, H. H.; Kalam, M. A.; Mahlia, T. M. I.; Husnawan, M.; Liaquat, A. M.; Renew. Sust. Energ. Rev. 2011, $15,220$.

46. Fazal, M. A.; Haseeb, A. S. M. A.; Masjuki, H. H.; Renewable Sustainable Energy Rev. 2011, 15, 1314.

47. Singh, B.; Korstad, J.; Sharma, Y. C.; Renewable Sustainable Energy Rev. 2012, 16, 3401.

48. Wang, H.; Tang, H.; Salley, S.; Ng, K. Y. S.; J. Am. Oil Chem. Soc. 2010, 87, 215.

49. Dunn, R. O.; Prog. Energy Combust. Sci. 2009, 35, 481.

50. Van Hoed, V.; Zyaykina, N.; De Greyt, W.; Maes, J.; Verhé, R.; Demeestere, K.; J. Am. Oil Chem. Soc. 2008, 85, 701.

51. Pieber, B.; Schober, S.; Goebl, C.; Mittelbach, M.; J. Chromatogr. A 2010, 1217, 6555.

52. Labeckas, G.; Slavinskas, S.; Renewable Energ. 2006, 31, 849.

53. Sgroi, M.; Bollito, G.; Saracco, G.; Specchia, S.; J. Power Sources 2005, 149, 8.

54. Pinzi, S.; Garcia, I. L.; Lopez-Gimenez, F. J.; Luque de Castro, M. D.; Dorado, G.; Dorado, M. P.; Energy Fuels 2009, 23, 2325.

55. CEN; Standard EN 14214, 2012, http://www.cen.eu/cen/pages/ default.aspx

56. ASTM; Standard D6751, 2011, doi: 10.1520/D6751-12.

57. Park, J.-Y.; Kim, D.-K.; Lee, J.-P.; Park, S.-C.; Kim, Y.-J.; Lee, J.-S.; Bioresour. Technol. 2008, 99, 1196.

58. Ramos, M. J.; Fernández, C. M.; Casas, A.; Rodríguez, L.; Pérez, Á.; Bioresour. Technol. 2009, 100, 261.

59. Moser, B. R.; Energy Fuels 2008, 22, 4301.

60. Sarin, R.; Sharma, M.; Sinharay, S.; Malhotra, R. K.; Fuel 2007, $86,1365$.

61. Zuleta, E. C.; Rios, L. A.; Benjumea, P. N.; Fuel Process. Technol. 2012, 102, 96.

62. Wanasundra, P. K. J. P. D.; Shahidi, F. In Bailey's Industrial Oil and Fat Products, vol. 1; Shahidi, F., ed.; Wiley-Interscience: New York, NY, USA, 2005, ch. 11.

63. Frankel, E. N., Symposium all Foods: Lipids alld their Oxidation; AVI Publishing Co.: Westport, CO, USA, 1962, p. 51. 
64. Erben-Russ, M.; Michel, C.; Bors, W.; Saran, M.; J. Phys. Chem. 1987, 91, 2362.

65. Frankel, E. N.; Bibl. Nutr. Dieta. 1989, 43, 297.

66. Baranescu, R.; Biodiesel Research - Engine Warranty Policy. Presented at Commercialization of Biodiesel: Establishment of Engine Warranties; University of Idaho National Center for Advanced Transportation, 1994, 102.

67. Sarin, A.; Arora, R.; Singh, N. P.; Sharma, M.; Malhotra, R. K.; Energy 2009, 34, 1271.

68. Sarin,A.; Arora, R.; Singh, N.; Sarin, R.; Sharma, M.; Malhotra, R.; J. Am. Oil Chem. Soc. 2010, 87, 567.

69. Brossia, C.; Pawlick, L.; Kelly, R. In Corrosion of Iron and Aluminum in Methanol Solutions; Paper 376, Corrosion >95, NACE: Houston, USA, 1995.

70. Sendzikiene, E.; Makareviciene, V.; Janulis, P.; Pol. J. Environ. Stud. 2005, 14, 335.

71. Hansen, A.; Zhang, Q.; Lyne, P.; Bioresour. Technol. 2005, 96, 27.

72. Domingos, A. K.; Saad, E. B.; Vechiatto, W. W. D.; Wilhelm, H. M.; Ramos, L. P.; J. Braz. Chem. Soc. 2007, 18, 416.

73. Kamiński, J.; Kurzydłowski, K.; Use of Impedance Spectroscopy to Testing Corrosion Resistance of Carbon Steel and Stainless Steel in Water-Biodiesel Configuration; J. Corros. Measur, 2008, http://www.korozja.pl/html/jcm/jcm_08_003.pdf accessed in March 2012.

74. Fazal, M. A.; Haseeb, A. S. M. A.; Masjuki, H. H.; Fuel Process. Technol. 2010, 91, 1308.

75. Niczke, L.; Czechowski, F.; Gawel, I.; Prog. Org. Coat. 2007, $59,304$.

76. Tsuchiya, T.; Shiotani, H.; Goto, S.; Sugiyama, G.; Maeda, A.; SAE Tech. Paper Series 2006, doi:10.4271/2006-01-3303

77. Tsuchiya, T.; Shiotani, H.; Goto, S.; Sugiyama, G.; Maeda, A., SAE Tech. Paper Series 2006-01-3303 2006, DOI 10.4271/2006-01-0126; Geller, D. P.; Adams, T. T.; Goodrum, J. W.; Pendergrass, J.; Fuel 2008, 87, 92.

78. Dodos, G. S.; Zannikos, F.; Stournas, S.; SAE Tech. Paper Series 2009, doi:10.4271/2009-01-1829

79. Mankowski, G.; Duthil, J.; Giusti, A.; Corros. Sci. 1997, 39, 27.

80. Notoya, T.; Hammamoto, T.; Corros. Eng. 1988, 37, 97.

81. Gil, H.; Leygraf, C.; J. Electrochem. Soc. 2007, 154, c272.
82. Gil, H.; Leygraf, C.; Tidblad, J.; J. Electrochem. Soc. 2012, 159, C123; Persson, D.; Leygraf, C.; J. Electrochem. Soc. 1985, 142, 1468.

83. Fazal, M.; Haseeb, A.; Masjuki, H.; Energy 2011, 36, 3328.

84. De Marco, R.; JIang, Z.; John, D.; Sercombe, M.; Kinsella, B.; Electrochim. Acta 2007, 52, 3746.

85. Emregül, K.; Aksüt, A. A.; Corros. Sci. 2000, 42, 2051.

86. Lee, W. J.; Pyun, S. I.; Electrochim. Acta 1999, 44, 4041; Doche, M.; Rameau, J.; Durand, R.; Novel-Cattin, F.; Corros. Sci. 1999, 41, 805.

87. Wang, J. B.; Wang, J. M.; Shao, H. B.; Zhang, J. Q.; Cao, C. N.; J. Appl. Electrochem. 2007, 37, 753.

88. El Abedin, S. Z.; Saleh, A.; J. Appl. Electrochem. 2004, 34, 331; Macdonald,D.D.; Real, S.; Smedley, S.I.;Urquidi MacDonald, M.; J. Electrochem. Soc. 1988, 135, 2410.

89. Champion, F. A.; Acebo, J. G.; Martínez, E. N.; Ensayos de Corrosión; Urmo, SA de Ediciones: España, 1976.

90. Díaz-Ballote, L.; López-Sansores, J.; Maldonado-López, L.; Garfias-Mesias, L.; Electrochem. Commun. 2009, 11, 41.

91. Lyman, T.; Boyer, H. E.; Committee, A. H.; Metals Handbook; American Society for Metals: USA, 1976.

92. Maru, M. M.; Lucchese, M. M.; Legnani, C.; Quirino, W. G.; Balbo, A.; Aranha, I. B.; Costa, L. T.; Vilani, C.; de Sena, L. A.; Damasceno, J. C.; Fuel Process. Technol. 2009, 90, 1175.

93. Thomas, E.; Fuller, R.; Terauchi, K.; SAE Tech. Paper Series 2007, doi:10.4271/2007-01-4061.

94. Haseeb, A. S. M. A.; Masjuki, H. H.; Siang, C. T.; Fazal, M. A.; Renewable Energ. 2010, 35, 2356.

95. Trakarnpruk, W.; Porntangjitlikit, S.; Renewable Energ. 2008, 33,1558 .

96. Bessee, G. B.; Fey, J. P.; SAE Tech. Paper No. 9716901997.

97. Haseeb, A.; Jun, T.; Fazal, M.; Masjuki, H.; Energy 2011, 36, 1814.

98. Terry, B.; McCormick, R. L.; Natarajan, M.; SAE Tech. Paper Series 2006-01-3279 2006, DOI 10.4271/2006-01-3279.

99. Mark, H. F.; Encyclopedia of Polymer Sceince and Technology; John Wiley \& Sons: USA, 2005.

Submitted: October 15, 2012

Published online: January 29, 2013 